\title{
Kortikosteroid sebagai Profilaksis Nefritis pada Purpura Henoch-Schonlein
}

\author{
Ratih Dewi Palupi, Zakiudin Munasir
}

Departemen Ilmu Kesehatan Anak, RS Dr Cipto Mangunkusumo, Fakultas Kedokteran Universitas Indonesia, Jakarta

Purpura Henoch-Schonlein (PHS) merupakan penyakit vaskulitis tersering pada anak. Sebagian besar kasus PHS bersifat sembuh sendiri (self-limiting). Morbiditas dan mortalitas jangka panjang PHS berkaitan dengan keterlibatan ginjal. Nefropati persisten terjadi pada $1 \%$ dari keseluruhan kasus PHS dan kurang dari $1 \%$ mengalami progresifitas menjadi gagal ginjal terminal. Tata laksana PHS terutama bersifat suportif. Kortikosteroid digunakan pada kasus PHS dengan nyeri perut, edema subkutan, dan nefritis. Penggunaan kortikosteroid sebagai profilaksis terjadinya gangguan ginjal pada PHS masih merupakan kontroversi. Pemberian kortikosteroid dini tidak dapat mencegah terjadinya keterlibatan ginjal pada PHS namun dapat mengurangi beratnya manifestasi gastrointestinal dan mengurangi risiko kelainan ginjal persisten. (Sari Pediatri 2010;11(6):409-14).

Kata kunci: purpura Henoch-Schonlein, kortikosteroid, profilaksis.

$\mathrm{P}$ urpura Henoch-Schonlein (PHS) adalah penyakit vaskulitis yang dapat mengenai kulit, sendi, gastrointestinal, ginjal, dan organ lainnya. Insidens PHS berkisar 13,5-18 per 100.000 anak. Penyakit ini dapat terjadi pada usia 6 bulan hingga dewasa, namun 50\% kasus terjadi pada anak berusia kurang dari 5 tahun, 75\% pada usia di bawah 10 tahun, dan banyak terjadi pada laki-laki. Kelainan PHS seringkali berkaitan dengan infeksi saluran napas sebelumnya, terutama infeksi streptokokus. ${ }^{1}$

The American College of Rheumatology membuat kriteria diagnosis PHS pada tahun 1990. Untuk

\section{Alamat korespondensi:}

Dr. Zakiudin Munasir, Sp.A(K). Divisi Alergi Imunologi Departemen Ilmu Kesehatan Anak FKUI-RSCM Jl. Salemba Raya no. 6, Jakarta 10430. Telepon: 021-3907744, 31901170. Fax: 021-3913982. menegakkan diagnosis PHS, dibutuhkan minimal dua dari empat kriteria yaitu,

- usia kurang dari 20 tahun saat awitan penyakit

- purpura yang dapat diraba

- bowel angina (nyeri perut difus atau iskemia usus yang biasanya berhubungan dengan terjadinya diare berdarah)

- biopsi kulit menunjukkan adanya granulosit di dinding arteriol atau venula.

Adanya dua atau lebih kriteria tersebut mempunyai sensitifitas $87,1 \%$ dan spesifisitas $87,7 \% .{ }^{1}$ Keterlibatan sendi terjadi pada 60\%-84\% kasus PHS, pada umumnya mengenai lutut dan pergelangan kaki. Gangguan gastrointestinal terjadi pada $76 \%$ pasien yang bervariasi dari kolik abdomen, mual, muntah, hingga perdarahan saluran cerna, intususepsi, dan pankreatitis. ${ }^{1}$ 
Morbiditas dan mortalitas jangka panjang PHS seringkali berkaitan dengan keterlibatan ginjal. Pada anak dengan gagal ginjal terminal, 5\%-15\% diantaranya disebabkan oleh PHS. ${ }^{2}$ Insidens kelainan ginjal pada PHS berkisar 10\%-60\%, 80\% diantaranya terjadi dalam 4 minggu pertama. Hematuria dengan atau tanpa proteinuria merupakan manifestasi ginjal tersering pada PHS. Sindrom nefritik akut dapat berkaitan dengan insufisiensi ginjal atau sindrom nefrotik. ${ }^{1}$

\section{Kasus}

Seorang anak perempuan berusia dua tahun satu bulan datang ke Poliklinik Tumbuh Kembang Bagian Ilmu Kesehatan Anak RSCM dengan keluhan timbul bercak-bercak merah di lengan, tungkai dan wajah sejak dua minggu sebelum masuk rumah sakit. Dua minggu sebelum masuk rumah sakit, pasien tampak lemas, terdapat batuk dan pilek, tidak terdapat demam, nafsu makan menurun, dan timbul bintik-bintik merah di tungkai. Pasien dibawa ke dokter, mendapat obat muntah dan sariawan namun tidak ada perbaikan sehingga diperiksakan kembali ke dokter dan mendapat antibiotik sefiksim selama tiga hari.

Satu minggu sebelum masuk rumah sakit, pasien dibawa ke rumah sakit karena tidak membaik, kemudian diperiksa darah dan dirawat inap, diberikan antibiotik injeksi dan diinfus. Empat hari sebelum masuk rumah sakit, timbul bercak-bercak merah berukuran $0,5-1 \mathrm{~cm}$, dapat diraba, awalnya di tungkai kemudian meluas ke wajah, kelopak mata, daun telinga, dan lengan. Pasien mengeluh batuk dan pilek, namun tidak demam, buang air besar biasa, dan buang air kecil berwarna kuning jernih. Pasien tidak mengeluh nyeri perut namun terdapat mual. Pasien dirujuk dari RS CH ke Poliklinik Tumbuh Kembang RSCM dengan keterangan suspek eritema nodosum dengan diagnosis banding sindrom Stevens Johnson dan penyakit Kawasaki.

Pasien adalah anak tunggal, berasal dari keluarga golongan sosial ekonomi menengah atas. Riwayat kehamilan, persalinan, dan tumbuh kembang normal. Imunisasi dasar lengkap, asupan nutrisi kesan cukup. Pada pemeriksaan fisis saat datang ke Paviliun Tumbuh Kembang Bagian Ilmu Kesehatan Anak RSCM, pasien kompos mentis, tidak sesak maupun sianosis, berat badan $11 \mathrm{~kg}$ dan tinggi badan $85 \mathrm{~cm}$ (gizi cukup).
Tanda vital berada dalam batas normal. Pada kulit, terlihat purpura multipel yang dapat diraba berukuran 0,5-1 cm di plantar pedis, kedua tungkai bawah, wajah, telinga, dan kedua lengan. Ekimosis terdapat pada kedua daun telinga. Pemeriksaan laboratorium menunjukkan hemoglobin $8,1 \mathrm{~g} / \mathrm{dL}$, leukosit 19.600/ $\mu \mathrm{L}$, trombosit $285000 / \mu \mathrm{L}$, albumin $1,7 \mathrm{~g} / \mathrm{dL}$, ureum $17 \mathrm{mg} / \mathrm{dL}$, kreatinin $0,5 \mathrm{mg} / \mathrm{dL}$, laju filtrasi glomerulus $85 \mathrm{~mL} / \mathrm{menit} / 1,73 \mathrm{~m}^{2}$. Urinalisis $\mathrm{pH} 6,0$, berat jenis 1,020, leukosit 10-15/lapang pandang besar (LPB), eritrosit 30-40/LPB, protein ( \pm ).

Pasien didiagnosis tersangka purpura HenochSchonlein dan mendapatkan triamsinolon $3 \times 4 \mathrm{mg}$ po $(1 \mathrm{mg} / \mathrm{kg} / \mathrm{hari})$ dan setirizin $2 \times 3 \mathrm{mg}$ po. Dalam perawatan, pasien mengalami nyeri perut dan perdarahan saluran cerna (hematemesis melena) sehingga diberikan metilprednisolon $3 \times 8 \mathrm{mg}$ iv (2 $\mathrm{mg} / \mathrm{kg} / \mathrm{hari}$ ) dan omeprazol $2 \times 10 \mathrm{mg}$ iv. Urinalisis $(10 / 3 / 2009)$ menunjukkan $\mathrm{pH} 7,5$, berat jenis $<1,005$, leukosit $0-3 / \mathrm{LPB}$, eritrosit $30-35 / \mathrm{LPB}$, protein $(+1)$. Hasil urinalisis (13/3/2009) menunjukkan leukosit 2-5/LPB, eritrosit 25-30/LPB, protein $(+2)$. Hasil biopsi kulit sesuai dengan vaskulitis leukositoklastik, tidak menunjukkan endapan baik imunoglobulin, C3 maupun fibrinogen.

Hasil konsultasi dengan divisi Nefrologi menyatakan diagnosis sesuai dengan nefritis HenochSchonlein dan dianjurkan terapi kombinasi dengan siklofosfamid (CPA) pulse atau CPA oral $2 \mathrm{mg} / \mathrm{kg} \mathrm{BB}$ selama 2 minggu, maka pasien mendapatkan CPA pulse $500 \mathrm{mg} / \mathrm{m}^{2}$ iv. Kortikosteroid intravena di tappering off dan diganti sediaan oral. Rasio protein dan kreatinin dalam urin sewaktu 13,7 (normal kurang dari 2) yaitu terdapat proteinuria masif sehingga ditambahkan kaptopril $2 \times 6,25 \mathrm{mg}$ po dan losartan ${ }^{\circledR} 1 \times 7,5 \mathrm{mg}$ po. Satu bulan kemudian, pasien mendapatkan CPA pulse yang kedua dengan dosis sama. Saat itu, hasil urinalisis (18/4/2009) menunjukkan leukosit 1-3/LPB, eritrosit 15-20/LPB, protein $(+3)$. Satu bulan kemudian, pasien mendapatkan CPA pulse yang ketiga dengan dosis sama. Saat itu, urinalisis (19/5/2009) menunjukkan leukosit 0-1/LPB, eritrosit 15-20/LPB, protein $(+2)$. Satu bulan kemudian, pasien mendapatkan CPA pulse yang keempat dengan dosis sama. Hasil urinalisis (22/6/2009) menunjukkan leukosit 1-3/LPB, eritrosit 20-25/LPB, protein (+2). Dosis kaptopril diturunkan menjadi $2 \times 3,125 \mathrm{mg}$ po, sedangkan dosis losartan tetap. Pasien direncanakan untuk mendapatkan CPA pulse yang kelima pada tanggal 22 Juli 2009. 


\section{Masalah klinis}

Nefritis menentukan prognosis PHS karena dapat mengakibatkan gagal ginjal dalam jangka panjang. Pada pasien kami, kortikosteroid tidak diberikan sejak awal penyakit sehingga keterlambatan ini mungkin mengakibatkan terjadinya komplikasi nefritis. Saat ini, belum terdapat konsensus mengenai efektifitas pemberian kortikosteroid untuk mencegah terjadinya komplikasi nefritis pada anak dengan PHS sehingga diformulasikan pertanyaan klinis sebagai berikut: "Pada anak dengan purpura Henoch-Schonlein, apakah pemberian kortikosteroid lebih baik dibandingkan dengan terapi suportif dalam mencegah terjadinya nefritis?"

\section{Penelusuran}

Prosedur pencarian literatur untuk menjawab masalah klinis adalah dengan menelusuri pustaka secara online dengan mempergunakan instrumen pencari Pubmed, Highwire, Cochrane Library, Google, dan Yahoo. Kata kunci yang dipergunakan adalah "purpura
Henoch Schonlein", "nephritis Henoch Schonlein", serta "corticosteroid", "therapy", "management" dengan menggunakan batasan: studi yang dilakukan pada manusia, publikasi bahasa Inggris, publikasi 20 tahun terakhir, anak usia 0-18 tahun, kata kunci terdapat pada judul, serta jenis publikasi berupa uji klinis, uji klinis terandomisasi, meta-analisis, dan review. Penelusuran lebih lanjut secara manual pada daftar pustaka yang relevan. Berdasarkan metode penelusuran dengan kriteria tercantum, didapatkan 18 artikel yang relevan. Penelusuran literatur dilanjutkan pada masingmasing abstrak dan didapatkan delapan artikel yang sesuai yaitu tiga uji klinis acak terkontrol dan lima artikel kohort. Levels of evidence ditentukan berdasarkan klasifikasi yang dikeluarkan oleh Oxford Centre for Evidence-based Medicine. ${ }^{3}$

\section{Hasil penelusuran}

Sebagian besar kasus PHS bersifat sembuh sendiri (self-limiting). Tata laksana PHS terutama bersifat suportif yang mencakup tirah baring, hidrasi, serta pemantauan timbulnya komplikasi gastrointestinal

Tabel 1. Ringkasan pemberian kortikosteroid pada PHS dari berbagai studi

\begin{tabular}{|c|c|c|c|c|c|}
\hline \multirow[t]{2}{*}{ Pengarang } & \multirow{2}{*}{$\begin{array}{c}\text { Besar } \\
\text { sampel }\end{array}$} & \multirow[t]{2}{*}{ Desain studi } & \multicolumn{2}{|c|}{ Dosis kortikosteroid } & \multirow{2}{*}{$\begin{array}{c}\text { Inisiasi } \\
\text { terapi setelah } \\
\text { diagnosis }\end{array}$} \\
\hline & & & $\begin{array}{l}\text { Dosis (mg/ } \\
\mathrm{kg} / \mathrm{hari})\end{array}$ & Durasi & \\
\hline $\begin{array}{l}\text { Ronkainen dkk } \\
\text { (2006) }\end{array}$ & 171 & $\begin{array}{l}\text { Uji prospektif, teracak, } \\
\text { kontrol placebo }\end{array}$ & 1 & $\begin{array}{l}2 \text { minggu, diturunkan } \\
\text { dalam } 2 \text { minggu }\end{array}$ & Saat diagnosis \\
\hline Huber dkk (2004) & 40 & $\begin{array}{l}\text { Uji prospektif, teracak, } \\
\text { kontrol placebo }\end{array}$ & 2 & $\begin{array}{l}1 \text { minggu, diturunkan } \\
\text { dalam } 1 \text { minggu }\end{array}$ & Saat diagnosis \\
\hline Mollica dkk (1992) & 168 & $\begin{array}{l}\text { Uji prospektif, teracak, } \\
\text { kontrol placebo }\end{array}$ & 1 & 2 minggu & Saat diagnosis \\
\hline Trapani dkk (2005) & 150 & Retrospektif & $1-2$ & $\begin{array}{l}\text { Rerata: } 13,7 \text { hari } \\
\text { (kisaran: } 7-32 \text { hari) }\end{array}$ & Tidak tercantum \\
\hline Saulsbury (1999) & 100 & Retrospektif & $1,6^{a}$ & $\begin{array}{l}\text { Rerata: } 8,9 \text { hari } \\
\text { (kisaran: 5-28 hari) }\end{array}$ & $\begin{array}{l}\text { Rerata: } 8,5 \text { hari } \\
\text { (kisaran: } 1-40 \text { hari) }\end{array}$ \\
\hline Saulsbury (1993) & 69 & Retrospektif & $1,7^{\mathrm{b}}$ & $\begin{array}{l}\text { Rerata: } 8 \text { hari (kisaran: } \\
\text { 5-10 hari) }\end{array}$ & $\begin{array}{l}\text { Rerata: } 5 \text { hari (kisaran: } \\
1-19 \text { hari) }\end{array}$ \\
\hline $\begin{array}{l}\text { Buchanec dkk } \\
\text { (1998) }\end{array}$ & 39 & Retrospektif & $1-2,5$ & $\begin{array}{l}10 \text { hari, diturunkan } \\
\text { dalam } 1-2 \text { minggu }\end{array}$ & Saat diagnosis \\
\hline $\begin{array}{l}\text { Rosenblum dan } \\
\text { Winter (1987) }\end{array}$ & 43 & Retrospektif & $1-2$ & Tidak tercantum & $\begin{array}{l}<1 \text { minggu }(75 \%),<12 \\
\text { hari }(96 \%)\end{array}$ \\
\hline
\end{tabular}

${ }^{a}$ Rerata dosis: 1,6 mg/kg BB/hari (kisaran: 1,2-2,0 mg/kg BB/hari)

${ }^{\mathrm{b}}$ Rerata dosis: $1,7 \mathrm{mg} / \mathrm{kg} \mathrm{BB} /$ hari (kisaran: $1,3-2,1 \mathrm{mg} / \mathrm{kg} \mathrm{BB} / \mathrm{hari}$ ) 
dan ginjal. Pada nyeri sendi, NSAID dapat membantu dan tidak menyebabkan purpura bertambah berat, namun obat ini harus digunakan dengan hati-hati pada pasien dengan insufisiensi ginjal dan perdarahan saluran cerna. ${ }^{4}$

Kortikosteroid digunakan pada kasus PHS dengan nyeri perut, edema subkutan, dan nefritis walaupun belum terdapat kesepakatan mengenai efektifitasnya. Kortikosteroid digunakan pada pasien dengan manifestasi gastrointestinal, terutama pada pasien dengan nyeri perut berat. ${ }^{2}$ Walaupun nyeri perut dapat membaik tanpa pemberian kortikosteroid, Rosenblum ND dan Winter $\mathrm{HS}^{5}$ melaporkan adanya perbaikan yang lebih cepat dengan kortikosteroid yaitu dalam 24 jam pertama pada 50\% anak, dibandingkan dengan $14 \%$ anak yang tidak mendapatkan kortikosteroid (level of evidence: $3 b$ ).

Saulsbury meneliti 100 anak dengan PHS dan menyatakan bahwa kortikosteroid mungkin bermanfaat untuk mempercepat penyembuhan nyeri perut dan artritis, namun tidak dapat diambil kesimpulan dari studi tersebut mengingat tidak dilakukannya randomisasi maupun pemberian plasebo. Selain itu, kortikosteroid yang diberikan dini pada awal penyakit juga tidak dapat mencegah rekurensi (level of evidence: $2 b){ }^{6}$

Peran kortikosteroid dalam mencegah terjadinya komplikasi ginjal atau mengurangi keparahan komplikasi ginjal pada PHS masih kontroversial. Suatu telaah sistematis oleh Weiss PF $\mathrm{dkk}^{7}$ menyimpulkan bahwa pemberian kortikosteroid dini dapat mengurangi risiko terjadinya kelainan ginjal persisten (level of evidence: $2 a$ ).

Suatu studi prospektif teracak dengan kontrol

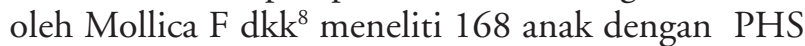
tanpa nefritis yang dirandomisasi untuk mendapatkan prednison $1 \mathrm{mg} / \mathrm{kg} /$ hari selama dua minggu. Pada kelompok yang mendapat prednison, tidak ada yang mengalami nefropati. Pada kelompok kontrol, 10 dari 84 anak mengalami nefropati dalam waktu 6 minggu, serta 2 orang kontrol lainnya mengalami nefropati pada waktu 24 dan 72 minggu (level of evidence: $2 b$ ). Studi retrospektif oleh Buchanec J dkk ${ }^{9}$ melaporkan bahwa nefropati terjadi pada 1 dari 23 pasien PHS (4,3\%) yang mendapatkan prednison dibandingkan dengan 5 dari 10 pasien (50\%) yang tidak mendapatkan prednison (level of evidence: $3 b$ ).

Suatu studi multivariat oleh Kaku Y dkk ${ }^{10}$ meneliti faktor-faktor yang mempengaruhi progresifitas keterlibatan ginjal pada 194 anak dengan PHS. Hasil dari studi tersebut menunjukkan bahwa kortikosteroid dapat menurunkan risiko terjadinya nefritis. Peneliti menganjurkan pemberian kortikosteroid secara dini pada pasien yang mempunyai faktor risiko terjadinya komplikasi ginjal. Faktor risiko tersebut meliputi gangguan gastrointestinal berat, purpura persisten (lebih dari satu bulan), dan penurunan aktifitas faktor XIII (level of evidence: 2b). Sebaliknya, studi retrospektif oleh Saulsbury FT ${ }^{11}$ pada 50 anak dengan PHS tanpa nefritis pada saat diagnosis menunjukkan frekuensi terjadinya nefritis yang sama baik pada anak yang mendapatkan kortikosteroid maupun tidak. Pada studi ini, nefritis yang terjadi lambat (lebih dari 3 minggu setelah urinalisis awal yang normal) terjadi pada 4 dari 20 pasien yang mendapatkan kortikosteroid, dan 6 dari 30 pasien yang tidak mendapatkan kortikosteroid (level of evidence: 36 ).

Suatu studi teracak dengan kontrol plasebo oleh Huber AM dkk ${ }^{12}$ pada 40 anak dengan PHS menunjukkan bahwa pemberian kortikosteroid dalam waktu tujuh hari setelah onset penyakit dapat menurunkan komplikasi ginjal atau gastrointestinal. Dua puluh satu subyek mendapatkan prednison oral $(2 \mathrm{mg} / \mathrm{kg} /$ hari selama $1 \mathrm{minggu}$, kemudian diturunkan bertahap pada minggu kedua), dan 19 orang mendapatkan plasebo. Disimpulkan bahwa pemberian prednison dini tidak dapat mengurangi risiko keterlibatan ginjal dalam waktu satu tahun atau risiko terjadinya komplikasi gastrointestinal akut, namun dapat mengurangi risiko terjadinya intususepsi. Huber AM dkk ${ }^{12}$ tidak menganjurkan pemberian prednison dini secara rutin pada pasien dengan PHS tanpa komplikasi (level of evidence: $2 b$ ).

Durasi rata-rata perjalanan penyakit PHS sekitar 4 minggu, namun dapat terjadi relaps. Kriteria relaps pada PHS yaitu timbul lesi kulit baru atau komplikasi sistemik pada pasien yang didiagnosis PHS dan asimtomatik selama minimal satu bulan. Saulsbury FT $^{6}$ melaporkan relaps pada anak dengan PHS 33\%. Suatu studi retrospektif oleh Trapani S dkk ${ }^{4}$ mendapatkan relaps lebih sering terjadi pada anak dengan PHS yang mendapatkan kortikosteroid. Pasien dengan penyakit yang lebih berat cenderung lebih sering mendapatkan kortikosteroid sehingga tingkat keparahan penyakit lebih bermakna sebagai faktor risiko relaps dibandingkan dengan hanya dengan kortikosteroid. Hubungan antara kortikosteroid dengan relaps menunjukkan suatu bias yang disebut sebagai confounding by 
indication. Relaps pada PHS sebaiknya dinilai dengan membagi pasien menjadi dua kelompok yaitu penyakit berat (manifestasi ginjal atau gastrointestinal berat) dan ringan (tidak adanya komplikasi). ${ }^{2}$

Studi retrospektif oleh Gonzalez-Gay dkk ${ }^{13}$ meneliti hubungan pemberian kortikosteroid dengan relaps pada 78 anak dengan PHS yang dipantau selama rata-rata 6 tahun. Enampuluh lima anak mengalami penyakit berat dan 20 orang diantaranya mendapatkan kortikosteroid, sedangkan pada 13 anak dengan penyakit ringan tidak satupun mendapatkan kortikosteroid $(\mathrm{p}=0,02)$. Ketika diteliti hubungan antara pemberian kortikosteroid dengan terjadinya relaps pada anak dengan PHS berat, terdapat korelasi yang kecil namun tidak signifikan $(\mathrm{OR}=1,39 ; \mathrm{p}=0,66)$ (level of evidence: $3 b$ ).

\section{Pembahasan}

Perjalanan penyakit PHS sebagian besar sembuh sendiri tanpa pengobatan, kortikosteroid diberikan pada kasus PHS dengan manifestasi gastrointestinal, terutama nyeri perut berat. Penggunaan kortikosteroid sebagai profilaksis terjadinya gangguan ginjal pada PHS masih merupakan kontroversi. Pada pasien kami terdapat keterlambatan pemberian kortikosteroid yaitu 2 minggu setelah timbulnya purpura. Kortikosteroid diberikan dengan dosis $1 \mathrm{mg} / \mathrm{kg} / \mathrm{hari}$, namun dalam pemantauan ditemukan adanya perdarahan saluran cerna, hematuria dan proteinuria sehingga dosis kortikosteroid diubah menjadi metilprednisolon $2 \mathrm{mg} /$ $\mathrm{kg} /$ hari. Keluhan perdarahan saluran cerna mengalami perbaikan namun hematuria dan proteinuria masih berlangsung. Gangguan gastrointestinal berat (seperti nyeri perut berat) pada PHS merupakan prediktor yang bermakna untuk terjadinya nefritis. ${ }^{14}$

Manifestasi nefritis pada pasien kami yaitu hematuria dan proteinuria. Pada nefritis PHS, manifestasi yang dapat terjadi antara lain hematuria, proteinuria, sindrom nefritik, atau sindrom nefrotik. Tata laksana nefritis pada pasien kami dengan pemberian siklofosfamid (CPA) pulse tiap 1 bulan yang hingga saat ini sudah masuk tiga kali, namun masih terdapat hematuria dan proteinuria sehingga pemberian CPA masih dilanjutkan. Tata laksana nefritis PHS masih bersifat kontroversial. Pasien dengan nefritis PHS berat diobati dengan kortikosteroid (oral atau pulse), atau dikombinasi dengan terapi lain seperti azatioprin, siklofosfamid, siklosporin, imunoglobulin dosis tinggi, dan plasmaferesis. ${ }^{4}$ Studi prospektif pada 12 pasien PHS dengan rapidly progressive glomerulonephritis menunjukkan adanya manfaat dari terapi intensif dengan menggunakan metilprednisolon, siklofosfamid, dipiridamol, dan prednison. Penggunaan imunoglobulin intravena pada PHS dikatakan dapat mengurangi nyeri perut dan gejala gastrointestinal lainnya. Studi pada sembilan anak dengan rapidly progressive nefritis PHS yang mendapatkan plasmaferesis sejak dini menunjukkan hasil yang cukup baik. ${ }^{15}$

Prognosis pada nefritis PHS bergantung pada berbagai faktor antara lain usia, manifestasi klinis, dan gambaran histologi. Pada anak, PHS biasanya bersifat lebih ringan, durasi lebih singkat, rekurensi lebih jarang, komplikasi ginjal dan gastrointestinal lebih sedikit. Nefritis dengan hematuria transien tanpa gangguan fungsi ginjal lebih banyak terjadi pada anak dibandingkan dewasa. Jika terdapat indikasi biopsi ginjal (misal protein urin lebih dari 1 gram/hari dan/ atau terdapat insufisiensi ginjal), risiko terjadinya gagal ginjal kronik $18 \%$ pada anak dan $28 \%$ pada dewasa. Pasien yang hanya mempunyai gejala hematuria mikroskopik biasanya akan mengalami penyembuhan sempurna, sedangkan pasien dengan sindrom nefritik akut atau proteinuria lebih dari 1 gram/hari akan mempunyai prognosis yang lebih buruk, terutama bila terjadi sindrom nefrotik. ${ }^{15}$ Gejala gastrointestinal berat, purpura persisten, dan usia onset di atas 7 tahun merupakan faktor risiko untuk terjadinya gagal ginjal pada PHS. ${ }^{10}$ Faktor prognostik yang paling akurat adalah gambaran histologi. Persentase gambaran bulan sabit (crescents), fibrosis interstisial, dan deposit mesangial pada biopsi ginjal berkaitan dengan risiko terjadinya gagal ginjal kronik. Risiko terbesar terdapat pada anak dengan gambaran crescents lebih dari 50\% glomerulus. ${ }^{15}$

Semua anak dengan sindrom nefritik atau nefrotik, atau insufisiensi ginjal pada PHS perlu dilakukan pemantauan jangka panjang. Anak dengan urinalisis normal pada umumnya tidak mengalami gangguan ginjal dalam jangka panjang. Risiko gangguan ginjal 12 kali lebih tinggi jika pada awal penyakit terjadi sindrom nefritik atau nefrotik dibandingkan dengan urinalisis yang abnormal saja, dan 2,5 kali lebih tinggi pada perempuan dibandingkan laki-laki. Bila urinalisis saat awal normal, tetap diperlukan pemantauan hingga enam bulan pertama. Bila dalam pemantauan enam bulan urinalisis tetap normal tidak diperlukan 
pemantauan lagi, namun bila terjadi abnormalitas urinalisis maka diperlukan pengukuran ureum dan kreatinin. ${ }^{16}$ Semua anak dengan nefritis PHS memerlukan pemantauan jangka panjang, khususnya saat dan setelah hamil karena dapat terjadi eksaserbasi. ${ }^{17}$ Pasien kami memerlukan pemantauan jangka panjang karena terdapat risiko terjadinya gagal ginjal kronik. Prognosis jangka panjang pasien PHS bergantung pada derajat beratnya keterlibatan ginjal. Pada pasien PHS yang mempunyai faktor risiko gangguan ginjal, terutama proteinuria, perlu dilakukan urinalisis selama minimal 3 bulan setelah onset penyakit. ${ }^{18}$ Nefropati persisten terjadi pada 1\% dari keseluruhan kasus PHS dan kurang dari $1 \%$ mengalami progresifitas menjadi gagal ginjal terminal. ${ }^{19}$

\section{Kesimpulan}

Pemberian kortikosteroid dini tidak dapat mencegah terjadinya keterlibatan ginjal pada PHS namun dapat mengurangi beratnya manifestasi gastrointestinal dan mengurangi risiko kelainan ginjal persisten.

\section{Daftar Pustaka}

1. Tizard EJ. Henoch-Schonlein purpura. Arch Dis Child 1999;80:380-3.

2. Gonzalez-Gay MA, Llorca J. Controversies on the use of corticosteroid therapy in children with Henoch-Schonlein purpura. Semin Arthritis Rheum 2005;35:135-7.

3. Oxford Centre of Evidence-based Medicine. Oxford Centre of Evidence-based Medicine Levels of Evidence. Diunduh dari: http://www.cebm.net/index aspx? $0=1025$ 2009.

4. Trapani S, Micheli A, Grisolia F, Resti M, Chiappini E, Falcini F, dkk. Henoch Schonlein purpura in childhood: Epidemiological and clinical analysis of 150 cases over a 5 -year period and review of literature. Semin Arthritis Rheum 2005;35:143-53.

5. Rosenblum ND, Winter HS. Steroid effects on the course of abdominal pain in children with Henoch-Schonlein purpura. Pediatrics 1987;79:1018-21.

6. Saulsbury FT. Henoch-Schonlein purpura in children: Report of 100 patients and review of the literature. Medicine 1999;78:395-409.
7. Weiss PF, Feinstein JA, Luan X. Effects of corticosteroid on Henoch-Schonlein purpura: a systematic review. Pediatrics 2007;120:1079-87.

8. Mollica F, Li Volti S, Garozzo R, Russo G. Effectiveness of early prednisone treatment in preventing the development of nephropathy in anaphylactoid purpura. Eur J Pediatr 1992;151:140-4.

9. Buchanec J, Galanda V, Belakova S, Minarik M, Zibolen M. Incidence of renal complications in Schonlein-Henoch purpura syndrome in dependence of an early administration of steroids. Int Urol Nephrol 1998;20:409-12.

10. Kaku Y, Nohara K, Honda S. Renal involvement in Henoch-Schonlein purpura: A multivariate analysis of prognostic factors. Kidney Int 1998;53:1755-9.

11. Saulsbury FT. Corticosteroid therapy does not prevent nephritis in Henoch-Schonlein purpura. Pediatr Nephrol 1993;7:69-71.

12. Huber AM, King J, McLaine P, Klassen T, Pothos M. A randomized, placebo-controlled trial of prednisone in early Henoch Schonlein Purpura. BMC Med 2004;2:7.

13. Gonzalez-Gay MA, Calvino MC, Vazquez-Lopez ME, Garcia-Porrua C, Fernandez-Iglesias JL, Dierssen T, $\mathrm{dkk}$. Implications of upper respiratory tract infections and drugs in the clinical spectrum of HenochSchonlein purpura in children. Clin Exp Rheumatol 2004;22:781-4.

14. De Almeida JL, Campos LM, Paim LB, Leone C, Koch $\mathrm{VH}$, Silva CA. Renal involvement in Henoch-Schonlein purpura: a multivariate analysis of initial prognostic factors. J Pediatr (Rio J) 2007;83:259-66.

15. Rai A, Nast C, Adler S. Henoch-Schonlein purpura nephritis. J Am Soc Nephrol 1999;10:2637-44.

16. Coppo R, Mazzucco G, Cagnoli L, Lupo A, Schena FP. Long-term prognosis of Henoch-Schonlein nephritis in adults and children. Nephrol Dial Transplant 1997; 12:2277-83.

17. Ronkainen J, Nuutinen M, Koskimies O. The adult kidney 24 years after childhood HenochSchonlein purpura: a retrospective cohort study. Lancet 2002;360:666-70.

18. Sano H, Izumida M, Shimizu H, Ogawa Y. Risk factors of renal involvement and significant proteinuria in HenochSchonlein purpura. Eur J Pediatr 2002;161:196-201.

19. Lanzkowsky S, Lanzkowsky L, Lanzkowsky P. HenochSchonlein purpura. Pediatr Rev 1992;13:130-7. 